\title{
Ocular Adnexal Lymphoma TNM Finding v8
}

National Cancer Institute

\section{Source}

National Cancer Institute. Ocular Adnexal Lymphoma TNM Finding v8. NCI Thesaurus. Code C140851.

A finding about one or more characteristics of ocular adnexal lymphoma, following the rules of the TNM AJCC v8 classification system. The lymphomas staged according to this system are primary lymphomas arising in the ocular adnexa-namely, the conjunctiva, eyelids, lacrimal gland, lacrimal drainage apparatus, and other orbital tissues surrounding the eye. Secondary ocular adnexal lymphomas and intraocular lymphomas are staged according to the classification for Hodg kin and non-Hodgkin lymphoma. There is no prognostic stage grouping for ocular adnexal lymphomas. (from AJCC 8th Ed.) 